\title{
ANALISIS KUALITAS TIMPHAN UBI JALAR UNGU (Ipomoea batatas L) BERDASARKAN PERBEDAAN LAMA PENGUKUSAN DAN PENYIMPANAN BEKU
}

\author{
Cut Nilda, Yusriana, Novi Safriani, Yanti Meldasari Lubis, dan Muhammad Chalid Isra \\ Jurusan Teknologi Hasil Pertanian, Fakultas Pertanian, Universitas Syiah Kuala \\ Email: cutnilda@unsyiah.ac.id
}

\begin{abstract}
ABSTRAK
Penelitian ini bertujuan untuk mengetahui pengaruh lama pengukusan dan lama penyimpanan beku terhadap kualitas fisik dan hedonic timphan ubi jalar ungu. Penelitian ini menggunakan Rancangan Acak Lengkap (RAL) faktorial yang terdiri dari dua faktor yaitu lama pengukusan (K1 = 15 menit, $\mathrm{K} 2=30$ menit) dan lama penyimpanan beku (T1=2 minggu, $\mathrm{T} 2=4$ minggu dan $\mathrm{T} 3=6$ minggu). Hasil penelitian menunjukkan bahwa lama pengukusan berpengaruh nyata terhadap cooking time, hedonik warna dan aroma, sedangkan lama penyimpanan beku berpengaruh terhadap warna dan tekstur timphan secara hedonik. Hasil terbaik diperoleh pada perlakuan pengukusan 15 menit dan lama penyimpanan beku 2 minggu (K1T1) dengan kriteria cooking time 9.62 menit, cooking loss $11.41 \%$, tingkat penerimaan hedonik rasa (3.55), warna (4.13), aroma (4.33) dan tekstur (4.21).

Kata kunci-cooking loss; cooking time; hedonic, lama pengukusan, lama pembekuan, timphan
\end{abstract}

\section{PENDAHULUAN}

Timphan merupakan makanan khas Aceh yang berbentuk bulat panjang dengan tekstur sedikit kenyal dan dibungkus dengan daun pisang muda dan kemudian dikukus. Timphan umumnya terbuat dari bahan dasar tepung ketan yang dicampur dengan pisang atau labu, biasanya terdapat variasi isi seperti parutan kelapa atau srikaya (Wibowo dkk., 2010). Salah satu upaya untuk meningkatkan mutu timphan baik dari segi warna maupun nilai gizinya adalah dengan memanfaatkan ubi jalar ungu. Ubi jalar ungu masih belum diolah menjadi bahan tambahan pada pengolahan timphan, sehingga pengolahan timphan dengan penambahan ubi jalar ungu diharapkan dapat memberikan nilai tambah terhadap sifat fisik, organoleptik, dan nilai jual timphan tersebut serta dapat menjadi alternatif diversifikasi pangan. Selain itu, pemanfaatan ubi jalar ungu pada timphan dapat menambah nilai gizi, nilai jual, serta dapat menjadi alternatif pangan fungsional khas Aceh.

Salah satu faktor yang mempengaruhi mutu organoleptik timphan adalah proses pengukusan. Jika proses pengukusan terlalu lama, maka tekstur timphan yang dihasilkan akan sangat kenyal, namun jika waktu pengukusan terlalu singkat maka timphan tersebut tidak masak dengan baik. Biasanya waktu yang digunakan masyarakat Aceh untuk mengukus timphan bervariasi antara 15 sampai 30 menit. Suhu dan lama pengukusan akan berpengaruh pada jumlah pati yang tergelatinisasi dalam adonan. Ketika proses pengukusan berlangsung, jenis dan ukuran alat pengukus juga akan mempengaruhi kecukupan dan pemerataan panas dalam adonan (Angelia, 2008).

Pembuatan timphan membutuhkan waktu yang relatif lama sekitar 1,5 jam. Selain itu, singkatnya umur simpan dari timphan menjadi suatu masalah bagi konsumen, biasanya timphan hanya bertahan 1 sampai 2 hari jika disimpan pada suhu ruang. Salah satu upaya untuk memperpanjang masa simpan timphan adalah dengan pembekuan. Timphan beku dapat menghemat waktu penyajian (lebih praktis) tanpa mengubah ciri khas timphan. Makanan ini dapat dinikmati hanya dengan di thawing (penyegaran kembali bahan yang telah dibekukan) dan dikukus selama 2 menit..Selain dapat menghambat pertumbuhan mikroorganisme, pembekuan juga dapat mengawetkan bahan pangan dan tidak mengubah mutu produk selama penyimpanan (Amiarsi dkk, 2013). Penelitian ini bertujuan untuk mengkaji pengaruh lama pengukusan dan penyimpanan beku terhadap kualitas timphan.

\section{METODOLOGI PENELITIAN}

\section{A. Bahan dan Peralatan}

Bahan-bahan yang digunakan dalam penelitian ini antara lain ubi jalar ungu pekat yang diperoleh dari pasar Peunayong Banda Aceh, daun pisang, tepung beras ketan, gula pasir, garam, kelapa, telur ayam dan plastik selofan. 
Peralatan yang digunakan dalam penelitian ini adalah pisau, talenan, sendok, wadah plastik, timbangan analitik, kukusan, kain saring, lemari es (freezer), kompor, stopwatch, sendok pengaduk kayu, kain lap, panci stainless steel ukuran sedang, wajan, jepitan kue stainless steel dan blender.

\section{B. Rancangan Penelitian}

Penelitian ini menggunakan Rancangan Acak Lengkap (RAL) faktorial yang terdiri dari dua faktor yaitu lama pengukusan $(\mathrm{K})$ yaitu $\mathrm{K} 1=15$ menit, $\mathrm{K} 2=30$ menit dan lama penyimpanan beku (T) yaitu T1=2 minggu, T2=4 minggu dan T3=6 minggu. Kombinasi perlakuan adalah 6 dengan 3 kali ulangan sehingga didapatkan 18 satuan percobaan.

\section{Prosedur Penelitian}

\section{Pembuatan Pasta Ubi Jalar}

Ubi jalar ungu $1 \mathrm{~kg}$ sebagai bahan utama dicuci bersih, kemudian dikupas dan dipotong menjadi beberapa bagian. Selanjutnya ubi jalar ungu direbus dengan santan $250 \mathrm{ml}$ sampai mendidih. Ubi jalar ungu yang telah hancur dengan santan dipisahkan kotoran-kotoran seperti serat dan potongan ubi jalar ungu yang belum hancur, kemudian pasta ubi jalar ungu disaring dengan saringan sehingga didapat pasta yang halus.

\section{Pembuatan Selai Srikaya sebagai isi timphan}

Sebanyak 4 butir telur dimasukkan kedalam wajan dan ditambahkan $250 \mathrm{~g}$ gula pasir, santan kental $1000 \mathrm{ml}$ dan garam $10 \mathrm{~g}$, kemudian diaduk rata sampai semua bahan tercampur. Lalu ditambahkan 2 lembar daun pandan dan dimasak di dalam wajan dan diaduk menggunakan pengaduk kayu sampai berbulir dan matang selama \pm 30 menit.

\section{Pembuatan adonan timphan}

Sebanyak $350 \mathrm{~g}$ pasta ubi jalar ungu dicampurkan tepung beras ketan $250 \mathrm{~g}$ dan garam $2 \mathrm{~g}$, lalu diaduk sampai menjadi adonan kalis selama selama \pm 15 menit.

\section{Pembungkusan dengan Daun Pisang}

Pembungkusan dengan daun pisang dilakukan setelah semua adonan dan srikaya siap. Daun pisang diolesi minyak nabati, supaya adonan timphan tidak menempel di daun pisang saat dilepas setelah masak. Kemudian diletakkan adonan sebanyak $40 \mathrm{~g}$ dan dipipihkan di atas daun pisang lalu ditambahkan selai srikaya sebanyak $7 \mathrm{~g}$ di atas adonan lalu digulung, selanjutnya timphan dikukus selama 15 menit dan 30 menit (sesuai perlakuan).

\section{Pengemasan dan Pembekuan}

Timphan selanjutnya dikemas dalam plastik selofan, supaya ketika dibekukan timphan tidak mengalami dehidrasi. Timphan dimasukkan ke dalam freezer dengan suhu $-15^{\circ} \mathrm{C}$ dan disimpan selama 2, 4 dan 6 minggu (sesuai perlakuan) kemudian dianalisis.

\section{Analisis Produk}

Analisis dilakukan terhadap timphan beku yaitu cooking time, cooking loss, dan uji penerimaan hedonik (rasa, warna, aroma, tekstur).

a. Menurut (Subarna dkk, 2012), pengujian cooking loss timphan dilakukan dengan menimbang berat timphan beku sebelum direhidrasi (berat awal). Timphan beku dikukus selama 5 menit (rehidrasi) lalu ditimbang kembali (berat akhir). Dilakukan perhitungan \% cooking loss dengan rumus sebagai berikut :

$$
\% \text { cooking loss }=\frac{\text { berat awal-berat akhir }}{\text { berat awal }} \times 100 \%
$$

b. Cooking Time (Tan et al., 2009)

Timphan beku dikukus selama 5 menit, setiap 1 menit timphan diambil untuk dicek kematangannya menggunakan garpu. Pengukusan diberhentikan ketika timphan yang diambil sudah tidak terbentuk garis putih ketika ditekan menggunakan garpu. 


\section{HASIL DAN PEMBAHASAN}

\section{A. Cooking Time}

Cooking time merupakan waktu yang dibutuhkan bahan pangan untuk mencapai tingkat rehidrasi/penyerapan air yang maksimal sehingga tekstur dari bahan pangan tersebut menjadi lunak (Yunita dkk, 2013). Hasil uji cooking time terhadap timphan berkisar antara 7,57-12,91 menit dengan rata-rata 10,42 menit. Hasil sidik ragam menunjukkan bahwa lama pengukusan berpengaruh sangat nyata terhadap cooking time timphan. Pengaruh lama pengukusan terhadap cooking time timphan dilihat dari pada Gambar 1.

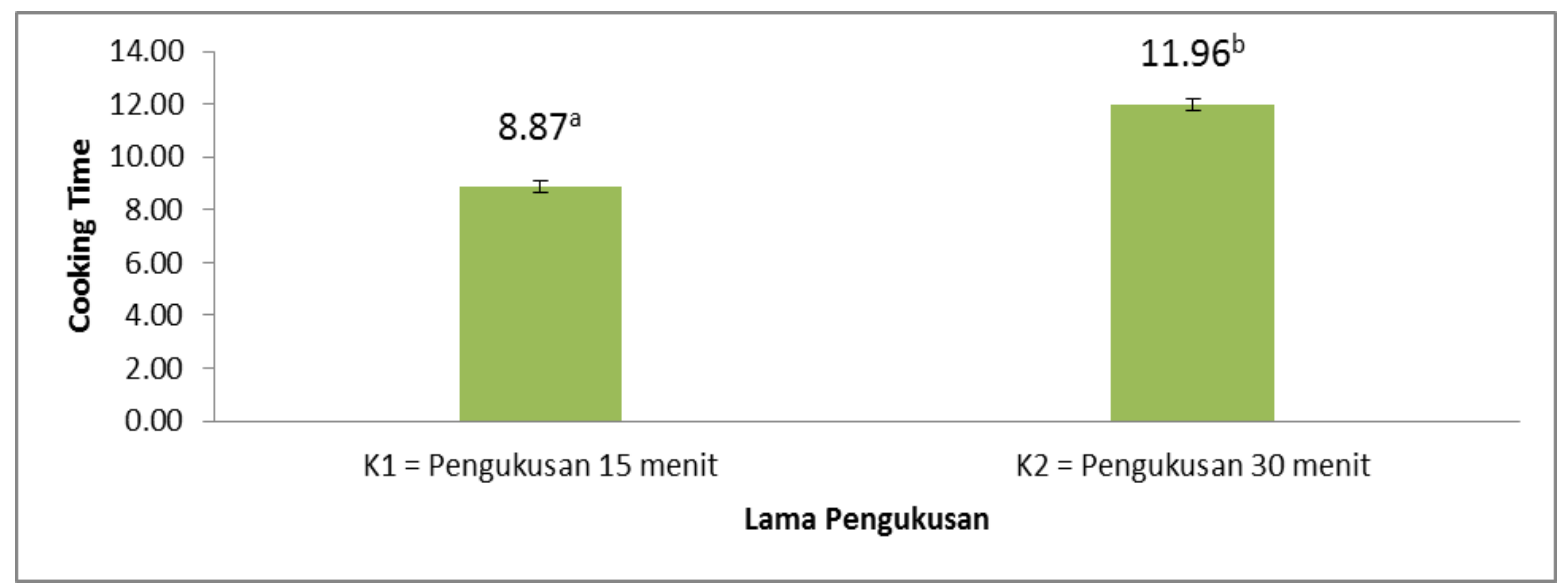

Gambar 1. Pengaruh Lama Pengukusan terhadap Cooking Time Timphan Beku Ubi Jalar Ungu $\left(\mathrm{BNT}_{0,01}=0,61, \mathrm{KK}=11,9 \%\right)$.

Gambar 1 menunjukkan bahwa lama pengukusan timphan rehidrasi ubi jalar ungu selama 15 menit dan 30 menit menunjukkan hasil yang berbeda. Nilai cooking time pada timphan beku ubi jalar ungu yang dikukus selama 30 menit lebih tinggi dari pada nilai cooking time 15 menit. Semakin lama waktu pengukusan maka cooking timenya semakin tinggi. Nilai cooking time timphan rehidrasi cenderung cukup tinggi yang menunjukkan kurangnya kemampuan timphan instan untuk menyerap air. Hal ini diduga disebabkan oleh pengaruh pasta ubi jalar ungu yang cenderung mempunyai viskositas tinggi dan kadar amilosa yang rendah (Nur Richana dkk, 2009) sehingga timphan tidak mampu menyerap air secara cepat.

\section{A. Cooking Loss}

Pada timphan rehidrasi, cooking loss didefinisikan sebagai persentase kehilangan berat produk selama rehidrasi, cooking loss mempengaruhi susut berat pada suatu bahan pangan. Menurut Subarna dkk (2012), cooking loss menunjukkan banyaknya padatan yang keluar selama proses pemasakan. Cooking loss timphan berkisar antara 10,42\% - 12,53\% dengan nilai rata-rata 11,10\%.

Hasil sidik ragam menunjukkan bahwa lama pengukusan (K), lama penyimpanan beku (T) dan interaksi diantara keduanya $(\mathrm{KT})$ berpengaruh tidak nyata $(\mathrm{P}>0,05)$ terhadap cooking loss timphan. Hal ini diduga karena pada saat pengukusan air terkandung dalam timphan tidak banyak yang keluar, sehingga tidak mempengaruhi cooking loss pada timphan tersebut. Rendahnya nilai cooking loss pada timphan komposit beku disebabkan oleh optimumnya pati mengikat air setelah terjadi gelatinisasi. (Eliason et al., 2012) menyatakan daya serap air yang dihasilkan berhubungan dengan sifat retrogradasi pati, dimana saat terjadinya retrogradasi amilosa yang keluar dari granula akan saling berikatan dengan sesama amilosa dan membentuk struktur yang kristalin. Saat terjadinya proses pemasakan kembali pati-pati yang keluar dari granula akan tertahan oleh struktur kristalin amilosa sehingga menurunkan jumlah pati yang terlarut.

\section{B. Uji Penerimaan (Hedonik)}

1. Rasa

Rasa merupakan salah satu parameter utama dalam penilaian organoleptic secara hedonic (Setyaningsih dkk, 2010). Hasil uji hedonik terhadap rasa timphan berkisar antara 3,13 (netral) - 4,07 
(suka) dengan rata-rata 3,51(suka). Hasil sidik ragam menunjukkan bahwa lama pengukusan dan lama penyimpanan beku tidak berpengaruh nyata terhadap organoleptik rasa timphan ubi jalar ungu. Hal ini mungkin disebabkan karena timphan telah dilapisi oleh daun pisang dan juga plastik selopan sehingga rasa dari timphan tetap terjaga.

\section{Warna}

Hasil uji hedonik terhadap warna timphan berkisar antara 3,19 (netral) - 4,13 (suka) dengan rata-rata 3,61(suka). Hasil sidik ragam menunjukkan bahwa lama pengukusan berpengaruh sangat nyata sedangkan lama penyimpanan beku berpengaruh nyata terhadap organoleptik warna timphan yang dihasilkan. Pengaruh lama pengukusan dan lama penyimpanan terhadap warna timphan yang dihasilkan dapat dilihat pada Gambar 2 dan 3.

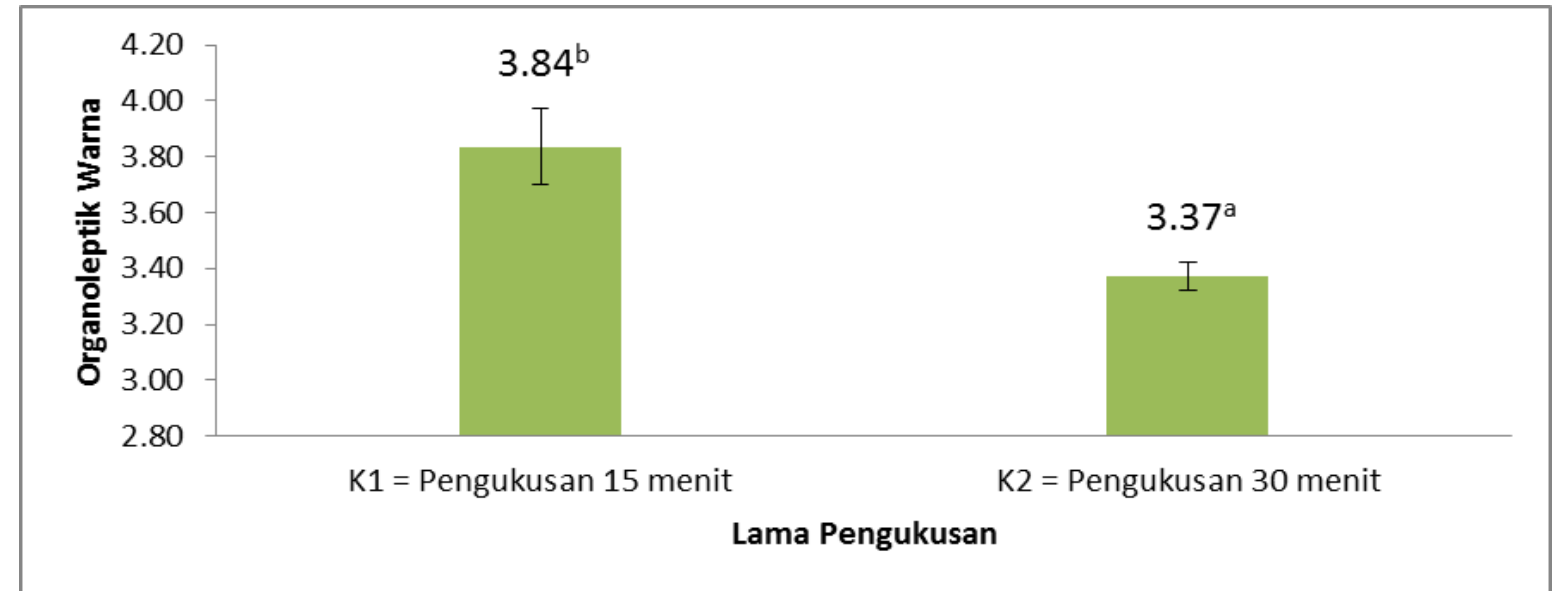

Gambar 2. Pengaruh Lama Pengukusan terhadap Uji Organoleptik Warna Timphan Ubi Jalar Ungu $\left(\mathrm{BNT}_{0,01}=0,16, \mathrm{KK}=9,03 \%\right)$

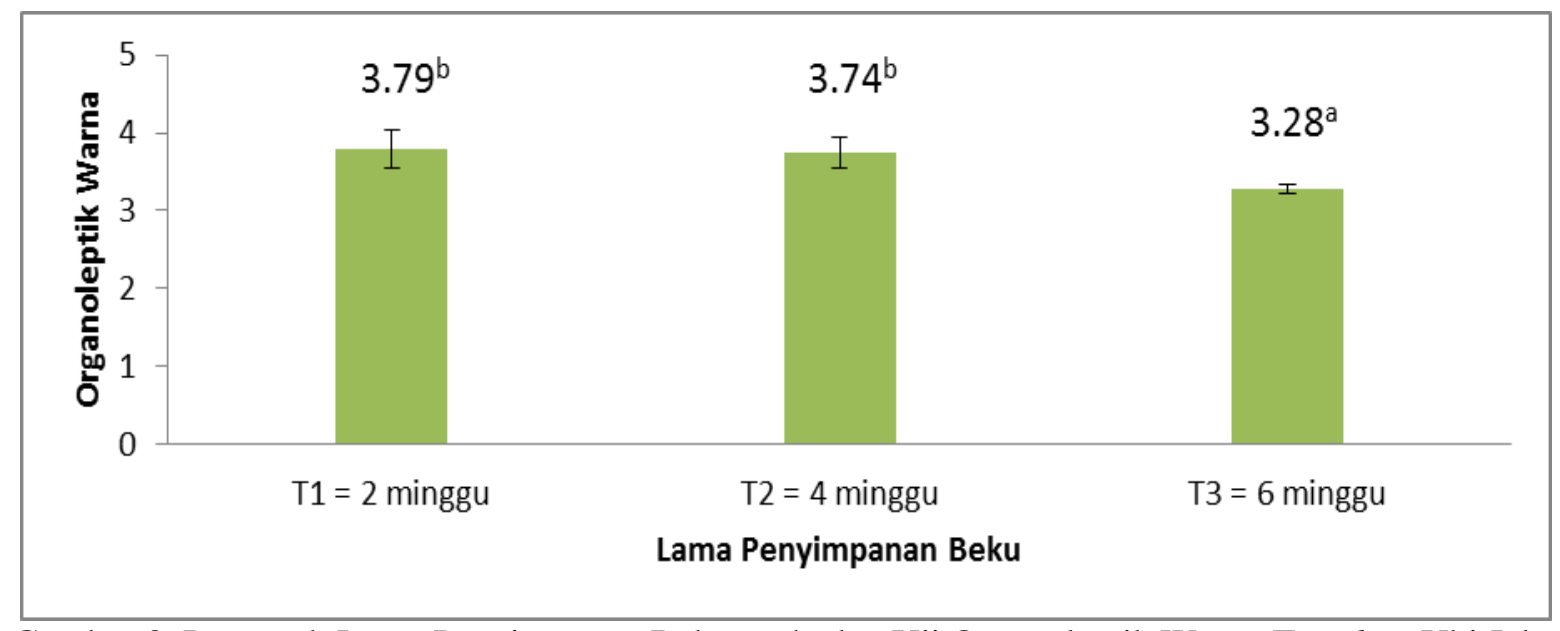

Gambar 3. Pengaruh Lama Penyimpanan Beku terhadap Uji Organoleptik Warna Timphan Ubi Jalar Ungu $\left(\mathrm{BNT}_{0,05}=0,17, \mathrm{KK}=9,03 \%\right)$

Pada penelitian ini warna timphan yang dikukus selama 15 menit, lebih disukai panelis dibandingkan dengan timphan yang dikukus selama 30 menit. Hal ini diduga karena warna ungu dari timphan yang dikukus selama 30 menit lebih pudar dibandingkan dengan timphan yang dikukus selama 15 menit. Hal ini sesuai dengan hasil penelitian (Husna dkk, 2013) yang menyatakan bahwa kadar antosianin yang terdapat pada ubi jalar ungu mengalami penurunan selama proses pengukusan.

Semakin lama penyimpanan dari timphan rehidrasi, maka warna ungu dari timphan semakin memudar, hal ini sama seperti yang disebutkan (Andarwulan dkk, 2012), degradasi antosianin dapat terjadi akibat proses penyimpanan. Semakin lama penyimpanan maka antosianin yang terkandung di dalam bahan akan menurun dan membuat warna produk pangan akan berkurang. 


\section{Aroma}

Hasil uji hedonik terhadap aroma timphan berkisar antara 3,33 (netral)- 4,33 (suka) dengan rata-rata 3,78 (suka). Hasil sidik ragam menunjukkan bahwa lama pengukusan $(\mathrm{K})$ berpengaruh sangat nyata terhadap organoleptik aroma timphan. Pengaruh lama pengukusan terhadap aroma timphan yang dihasilkan dapat dilihat pada Gambar 4.

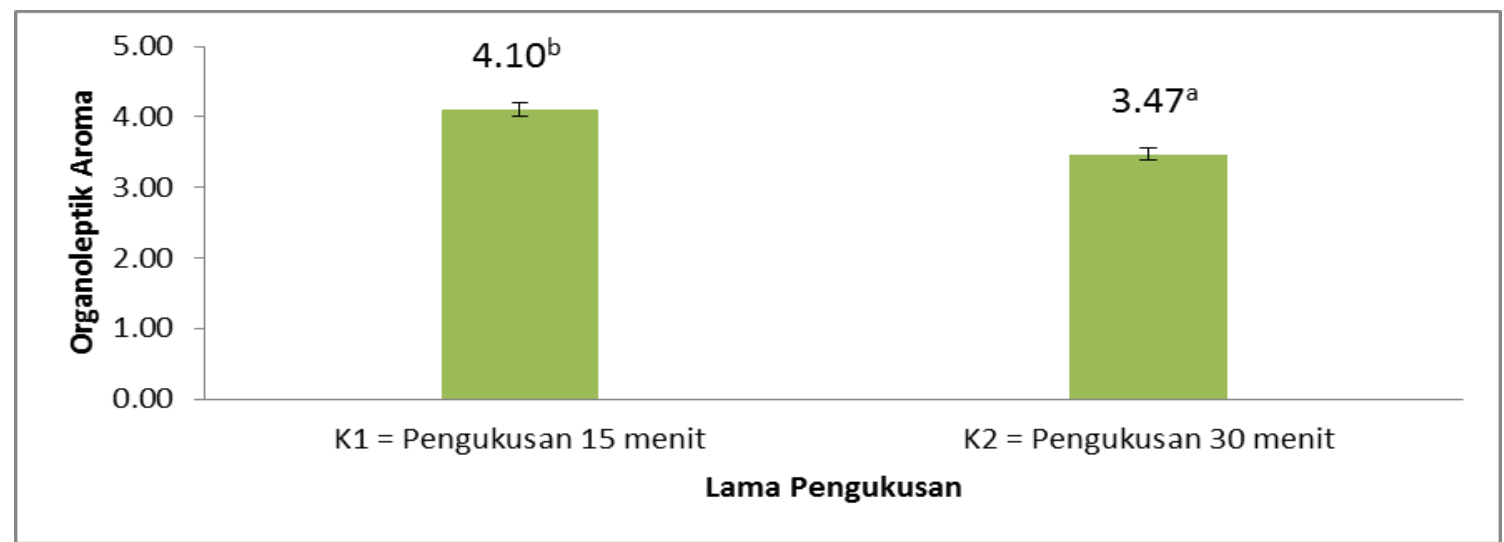

Gambar 4. Pengaruh lama pengukusan terhadap uji organoleptik aroma timphan ubi jalar ungu $\left(\mathrm{BNT}_{0,01}=0,17, \mathrm{KK}=9,60 \%\right)$

Gambar 4 menunjukkan bahwa lama pengukusan timphan ubi jalar ungu selama 15 menit memberikan perbedaan nilai hedonik aroma timphan ubi jalar ungu dibandingkan dengan pengukusan 30 menit. Panelis lebih menyukai timphan ubi jalar ungu yang dikukus selama 15 menit dari pada yang dikukus selama 30 menit. Hal ini diduga disebabkan karena timphan ubi jalar ungu yang dikukus selama 15 menit memiliki aroma ubi jalar ungu yang lebih khas. Timphan ubi jalar ungu yang dikukus selama 30 menit aroma dari ubi jalar ungu tidak tajam lagi sehingga panelis kurang menyukainya. Hal yang sama dinyatakan oleh Yunita dkk (2013), dimana timphan yang dikukus dalam waktu yang lama akan mengalami perubahan aroma. Oleh sebab itu untuk mencegah hal tersebut waktu pengukusan timphan dipersingkat.

\section{Tekstur}

Hasil uji hedonik terhadap tekstur timphan berkisar antara 3,3 (netral) - 4,2 (suka) dengan ratarata 3,7 (suka). Hasil sidik ragam menunjukkan bahwa lama penyimpanan beku berpengaruh nyata terhadap organoleptik tekstur timphan (Gambar 5).

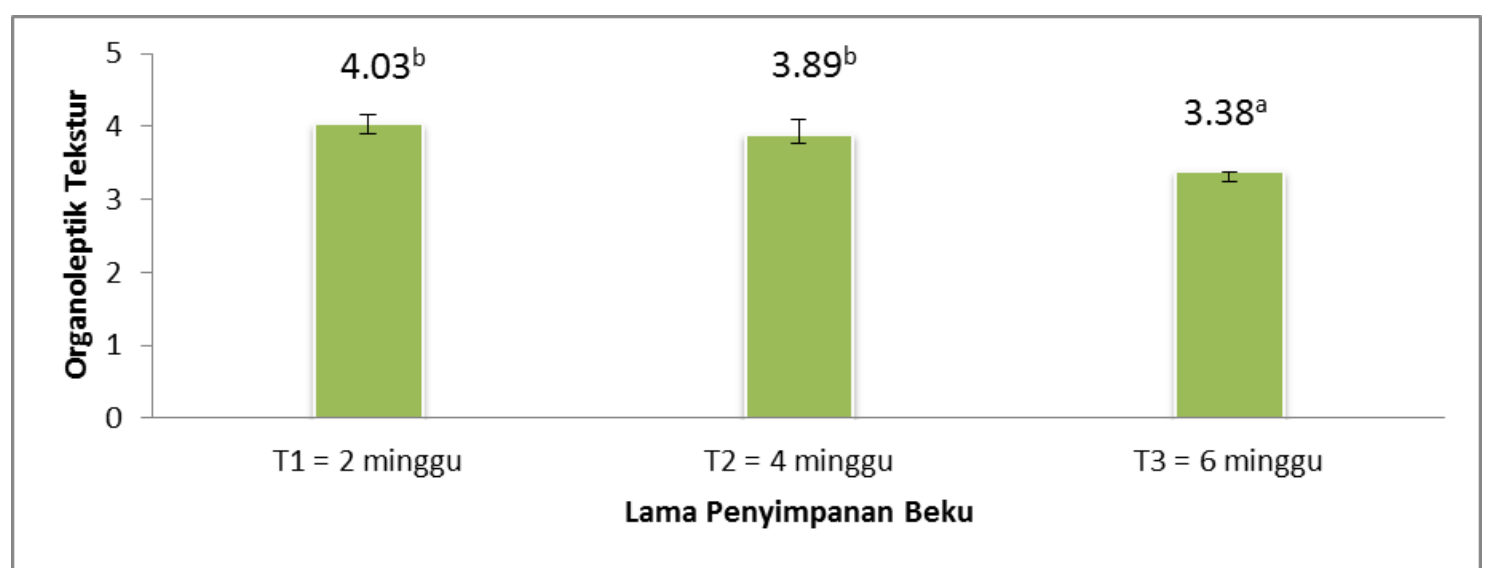

Gambar 3. Pengaruh lama penyimpanan beku terhadap uji organoleptik tekstur timphan ubi jalar ungu $\left(\mathrm{BNT}_{0,05}=0,22, \mathrm{KK}=11,28 \%\right)$

Dari Gambar 5 terlihat bahwa organoleptik tekstur timphan ubi jalar ungu menurun seiring dengan lama penyimpanan beku. Panelis cenderung menyukai timphan yang disimpan pada 2 minggu dan 4 minggu. Diduga selama penyimpanan tekstur menjadi kurang baik disebabkan oleh penurunan 
tingkat kekenyalan timphan yang juga berhubungan dengan cooking loss. Menurut (Meiriza dkk, 2016), semakin lama penyimpanan beku maka tekstur dari ikan bandeng dalam kemasan juga akan menurun. Kerusakan yang terjadi selama penyimpanan beku terjadi akibat adanya pembentukan radikal bebas dan hidroperoksida yang menyebabkan perubahan pigmen, rasa, dan tekstur.

\section{KESIMPULAN DAN SARAN}

Lama pengukusan berperngaruh nyata terhadap cooking time, hedonik warna dan aroma, sedangkan lama penyimpanan beku mempengaruhi penerimaan warna dan tekstur timphan. Hasil terbaik diperoleh pada perlakuan pengukusan 15 menit dan lama penyimpanan beku 2 minggu (K1T1) dengan kriteria cooking time 9.62 menit, cooking loss $11.41 \%$, tingkat penerimaan hedonik rasa (3.55), warna (4.13), aroma (4.33) dan tekstur (4.21).

Penelitian selanjutnya diharapkan dapat melakukan pengujian tekstur dengan LFRA untuk mengetahui tekstur timphan secara akurat dan juga pengujian warna menggunakan LAB untuk mengetahui secara pasti perubahan warna selama penyimpanan.

\section{DAFTAR PUSTAKA}

Amiarsi, D dan Mulyawanti, I. 2013. Pengaruh Metode Pembekuan Terhadap Karakteristik Irisan Buah Mangga Beku Selama Penyimpanan. J. Hort, 23, 255-262. Retrieved from.doi:10.21082/jhort.v23n3.2013.p255-262

Andarwulan, N dan Faradilla.R, H. 2012. Pewarna Alami Untuk Pangan. Bogor: Seafast center.

Angelia, M. 2008. Paket Teknologi Pembuatan Mie Kering dengan Memanfaatkan Bahan Baku Tepung Jagung. Institut Pertanian Bogor.

Eliason, A. C. and M. G. 2012. Starch: Physicochemical and Functional Aspect. In Eliason,a,c. (ed). Carbohydrate in Food. New York: Marcel Dekker.

Husna, N. E., Novita, M., Rohaya, S. 2013. Kandungan Antosianin dan Aktivitas Antioksidan Ubi Jalar Ungu Segar dan Produk Olahannya. Agritech, 33(3), 298.

Meiriza, Y., E. N Dewi, dan L. R. 2016. Perbedaan karakteristik ikan bandeng (Chanos chanos Forsk) cabut duri dalam kemasan berbeda selama peyimpanan beku. J. Peng. \& Biotek. Hasil $\mathrm{Pi}, 5(1), 36-43$.

Nur Richana dan Widaningrum. 2009. Penggunaan tepung dan pasta dari beberapa varietas ubi jalar sebagai bahan baku mi. J.Pascapanen, 6(1), 43-53.

Setyaningsih, D., A. Apriyantono., dan M. P. S. 2010. Analisis Sensori untuk Industri Pangan dan Agro. Bogor: IPB Press.

Subarna., T. Muhandri., B. Nurtama., dan A. S. F. 2012. Peningkatan mutu mie kering jagung dengan penerapan kondisi optimum proses dan penambahan monogliserida. Jurnal Teknologi dan Industri Pangan, 23(2), 146-152.

Tan, H.Z., Z.G. Li., dan B. T. 2009. 2009. Strarch noodles: history, classification, materials, processing, structure, neutrition, quality evaluating and improving. Food Research International, 42, 551-576.

Wibowo, A. B., S.S. Hasbullah., dan P. R. 2010. Suwa. Banda Aceh: Balai Kajian dan Nilai Tradisional.

Yunita, D., Husna, N. E., R. 2013. Perbaikan Tekstur Timphan Instan Melalui Modifikasi Cairan Pada Adonan Timphan, Tingkat Gelatinisasi dan Perlakuan Pembekuan. J. Sagu, 12(2), 17-22. 